\title{
Respect For Individual Limited Company (MSMEs) For Pailit Decision
}

\author{
Sabrina Isnintias, Moh.Saleh \\ Faculty of Law, Narotama University Surabaya \\ E-mail:isnintiassabrina@gmail.com
}

\begin{abstract}
Ratification of Law Number 11 of 2020 concerning Job Creation (Job Creation Law) brings blessings to Micro, Small and Medium Enterprises (MSMEs) entrepreneurs. Because it provides convenience, protection, and empowerment to MSMEs, it is one of the objectives of the creation of the Job Creation Law which is outlined in the form of a derivative, namely Government Regulation (PP) Number 8 Year 2021. The Job Creation Law is one of the breakthroughs of the Indonesian Government to restore a sluggish economy during the Covid-19 Pandemic, many business sector sectors were hindered and suffered many losses due to the pandemic situation. The PP explains that a Limited Liability Company can be established by 1 (one) founder, specifically PT. Individuals (MSMEs), where this provision raises various questions, one of which is a form of responsibility to a third party (BANK) if PT Individuals (MSMEs) are declared In a state of bankruptcy, the purpose of this study is to identify and analyze the legal aspects of PT Perseorangan's bankruptcy settlement. The benefits of this research are addressed to individual PT directors and legal experts who face similar cases.
\end{abstract}

Keywords : PT Individuals, MSMEs, Pailit

\section{INTRODUCTION}

In the current era of development, the Indonesian government is aggressively trying to make the Indonesian state progress, one of which is the omnibus law of the Job Creation Act which is predicted to be a creative breakthrough to advance the nation. Apart from the various controversies surrounding the discussion, the Job Creation Law is very reformative and phenomenal. For the first time, our government uses the omnibus law method comprehensively for a law. Our government argues that the Job Creation Law has a positive impact on economic growth and Indonesia's statutory regulations (Rusliati, 2020).

In the context of accelerating economic recovery, the Government has enacted Law Number 11 of 2020 concerning Job Creation (Job Creation Law) which was signed by President Joko Widodo on November 2, 2020, Yasonna emphasized that the Work Creation Law was drafted using the method It is hoped that the Omnibus Law will encourage the acceleration of economic growth through various facilities in doing business (Starting business), especially with the existence of an Individual Company which is a breakthrough to provide convenience for MSMEs in establishing companies that are legal entities. This individual company is established in a very simple way, namely the founder is only one person and enough with a statement of establishment, which is then registered with the Directorate General of General Legal Administration (Ditjen AHU) of the Ministry of Law and Human Rights (Kemenkumham) and does not require an announcement in an additional State Gazette. . For the sake of good and accountable corporate 
This work is licensed under a Creative Commons Attribution-ShareAlike 4.0 International License

governance, Individual Companies will also conduct financial reports every year electronically. The Ministry of Law and Human Rights will provide a format for individual company financial statements that is very simple and available on the website www.ahu.go.id.JobThrough thisCreation Law, the government cuts regulations that impede both the central and regional levels and makes doing business easier, especially for the MSMEs sector.

As is known, the omnibus law of the Job Creation Law has been officially signed by President Joko Widodo and promulgated as Law Number 11 of 2020. After being signed, the Minister of State Secretary through the Deputy for Law and Legislation with letter No: B-437 / Kemensetneg / D-1 / HK.00 / 11/2020 dated 2 November 2020 requested that this law be promulgated in the Republic of Indonesia State Gazette as well as in the Supplement to the Republic of Indonesia's State Gazette. On the same date, this Law was also signed by the Minister of Law and Human Rights Yasonna Laoly and entered the State Gazette of the Republic of Indonesia Year 2020 Number 245. One of the goals of the Job Creation Law is to create employment and entrepreneurship through the Ease of Doing Business, namely easily obtaining permits, special treatment for MSEs (Medium and Small Enterprises), easy to obtain business legality (legal entity).

In the last few years, the Government of Indonesia has consistently made gradual improvements to the ease of doing business process. One of the initiatives is launching the Online Single Submission (OSS) system in 2018, which serves as the only gateway for applying for business licenses. Through the OSS platform we are introduced to a Business Identification Number (NIB) which must be owned by all business actors regardless of their form of business including Limited Liability Companies (PT). Apart from being required when applying for a business license at OSS, the NIB obtained also applies as a Company Registration Certificate (TDP), Import Identification Number (API), and customs access rights. That way, after the process of establishing a Limited Liability Company (PT) is completed, it can operate for profit, then it can immediately apply for an NIB and business license for the PT electronically through OSS. All of this was done without having to go to more than one agency repeatedly carrying a pile of documents. This OSS procedure is considered to shorten the time and process of establishing PT. Since its launch, OSS has made various improvements to simplify and clarify the process of obtaining a business license.

In Law No. 40 of 2007 (UUPT), PT is defined as a legal entity that is a capital alliance, established based on an agreement, conducting business activities with authorized capital which is entirely divided into shares and fulfills the requirements stipulated in the Company Law and its implementing regulations (Yustianti \& Roesli, 2018). PT must be established by a minimum of 2 people. However, this provision does not apply to PT whose shares are wholly owned by the state 
This work is licensed under a Creative Commons Attribution-ShareAlike 4.0 International License

or to PT which manages stock exchanges, clearing and guarantee institutions, depository and settlement institutions, and other institutions regulated in the Capital Market Law. After the entry into force of the Job Creation Law, the definition of a PT was changed to a legal entity which is a capital alliance, established based on an agreement, carrying out business activities with authorized capital wholly divided into shares or individual legal entities that meet the criteria for Micro and Small Businesses as stipulated in the Laws and Regulations. -The Act on Micro and Small Enterprises, namely Government Regulation number 8 of 2021, the Company's Authorized Capital and Registration of Establishment.

The obligations of PTs that are established by at least 2 people also experience changes, namely the increase in types of PT, one of which is a PT that meets the criteria for Micro and Small Enterprises. That way, we can establish a PT alone without having to find a partner as long as the business is carried out according to the criteria. Micro and Small Enterprises. In addition, in contrast to PT in general, the process of establishing a PT for Micro and Small Enterprises does not require a deed of establishment, but it is sufficient to use a statement of incorporation in Indonesian.

In establishing an individual PT, PT owners certainly do not rule out wanting to get additional capital to develop their business, a path that is often taken by PT owners, namely by involving the Bank. By applying for a capital loan so that the business being managed can run smoothly without being constrained. However, not everything that has been carefully planned always goes well, sometimes business people (debtors) have difficulty fulfilling their achievements to creditors, due to various things either because of lack of customers or due to negligence in managing the business, especially the PT was declared bankrupt. by the Court.

If PT Persekutuan capital is in a state of bankruptcy, the PT will inevitably be dissolved, by holding a General Meeting of Shareholders (GMS) Decision in the form of a Notary Deed and appointing a Liquidator (Board of Directors or other party), however, in contrast to a private PT, the dissolution of an individual company is stipulated by the decision of the individual shareholders of the Company which has the same legal force as the general meeting of shareholders which is set forth in the Declaration of winding up and notified electronically to the Minister. In Article 13 paragraph (1) Government Regulation Number 8 Year 2021 explains that in an individual PT, in the event of Dissolution, PT Individuals will make a statement of dissolution, then Article 13 paragraph (3) and paragraph (4) states that the shareholders of PT. This single individual appoints a liquidator, in the event that the shareholder does not appoint a liquidator, the board of directors acts as a liquidator, namely the board of directors or owners of PT. So that only 1 (one) person, namely the sole owner of the PT, the sole owner of PT. Individuals can become the liquidator, and the Liquidator and Owner of PT. Individuals are also the same person. There is no 
This work is licensed under a Creative Commons Attribution-ShareAlike 4.0 International License

detailed or clear explanation of the responsibility given to whom, and how the liquidator's accountability mechanism to third parties or the Bank. This Government Regulation Number 8 of 2021 only regulates the establishment, amendment, dissolution in a simple manner, but for accountability to third parties there is no detailed and clear explanation. What are the legal consequences when PT.Perseorangan is declared bankrupt in connection with a third party (BANK)? And What is the form of legal protection for a third party (BANK) when a private PT (MSMEs) is declared bankrupt.

\section{RESEARCH METHOD}

This research is a normative juridical legal research which aims to find laws and regulations, legal principles and doctrines to overcome current legal problems. (Peter Marzuki: 2011) Besides that. This study is a descriptive qualitative analytical study. Literature study is used as a research method considering the study of the legal form of individual PTs can be carried out through tracing concepts, government regulations, and implementation through primary legal materials in the form of laws and regulations, secondary materials in the form of books, journals, news.

\section{RESULTS AND DISCUSSION}

Legal Consequences When PT.Perseorangan is declared bankrupt in connection with a third party (BANK)

\section{Establishment of PT. Individuals (MSMEs)}

In establishing a company, it must be based on the prevailing laws and regulations, especially in Law Number 40 of 2007 concerning Limited Liability Companies. hereinafter referred to as UUPT, although the Company Law is classified as an economic law specifically regulating the corporate law sector, not all the provisions contained therein are compelling (dwingenrecht, mandatory law). Many of the substances are regulating (aanvuelendrecht, directory rule) (Yahya Harahap: 2019) The establishment of a limited liability company (PT) can be done by one person. This provision is a mandate from Law Number 11 of 2020 concerning Job Creation to support ease of doing business. The implementing regulations for the establishment of individual PTs are contained in Government Regulation (PP) No.8 of 2021 concerning the Authorized Capital of Companies and the Registration of Establishment, Amendment and Disbanding of Companies that Meet the Criteria for Micro and Small Businesses. In the old provisions, the establishment of a PT at least two people and there was a minimum authorized capital limit was considered to be one of the obstacles for business actors. However, the establishment of an individual PT has procedures and requirements that must be met by business actors. An individual PT can only be established for 
This work is licensed under a Creative Commons Attribution-ShareAlike 4.0 International License

the criteria of micro and small businesses. The criteria for a micro business are determined based on a maximum working capital of Rp. 1 billion, excluding land and buildings for business premises or annual sales proceeds of a maximum of Rp. 2 billion.

Meanwhile, small businesses are determined based on ownership of business capital of more than IDR 1 billion-IDR 5 billion excluding land and buildings for your business or have annual sales of more than IDR 2 billion-IDR 15 billion. This provision is contained in Government Regulation Number 7 of 2021 concerning Ease, Protection, and Empowerment of Cooperatives and Micro, Small and Medium Enterprises. MSMEs have a contribution of 60.3 percent of the total Gross Domestic Product of Indonesia, and based on the records of the Central Bureau of Statistics, they absorb the most workforce, amounting to 97 percent and 99 percent of total employment. The increase in the number of MSMEs, in a period of 2 years from 2018, is above 8 million people, namely 64.2 million MSMEs, although it is important to underline the estimates that there are quite a lot of recurring data records on the same MSMEs actors. The form of micro, small and medium enterprises refers to Article 1 of Law Number 20 of 2008 concerning Micro, Small and Medium Enterprises in the form of individual businesses. Abdulkadir Muhammad explained that a trading company or an individual company business is a company established and owned by an entrepreneur covering the types of companies trading, service companies and industrial companies. (Dijan Widijowati: 2012).

This company also has no obligation to get approval from its business partners or those we know other Directors because of its singular nature, so its dissolution does not require the approval of other parties. A term known in public such as a Trading Company (PD) or a Trading Business (UD) is basically an individual company. The formation of an individual PT is a form of development from a PT which was originally only allowed to be established by two or more people. Chewaka (2016) states that the formation of the individual PT model is the result of the natural nature of the desire of everyone who wants to form a company with limited responsibilities, but can be founded by only one person (Zainal Asikin \& Wira Pria Suhartana: 2016)

The establishment of an Individual Company may only be made by Indonesian Citizens (WNI). The Indonesian citizen must be at least 17 years old and legally competent (Article 6 PP Company). It is sufficient for the establishment of an Individual Company to make a Statement of Establishment in Indonesian. The Statement of Establishment is registered electronically with the Minister of Law and Human Rights with the following contents (Article 7 PP Company):

1. Name and domicile of Individual Company;

2. The period of establishment of an Individual Company;

3. Purpose and objectives and business activities of an individual Company;

4. Total authorized capital, issued capital, and paid up capital; 
5. The nominal value and number of shares;

6. Address of the individual company; and

7. The full name, place and date of birth, occupation, residence, resident registration number, and tax identification number of the founder as well as the director and shareholder of an individual Company.

After that, the Individual Company will get the status of a legal entity by obtaining an electronic registration certificate (Article 6 PP Company). The status of the legal entity is announced on the official page https://ahu.go.id/. Change of Legal Entity Status of Individual Companies is a special legal entity, which is intended for MSMEs. Therefore, there are several conditions that make an Individual Company have to change its legal entity status to become a Company in general, namely as follows (Article 9 PP Company): shareholders become more than 1 (one) person; and / or no longer meet the MSE criteria. Regarding MSE criteria, you can see the criteria in Articles 35-36 of Government Regulation Number 7 of 2021 concerning Ease, Protection and Empowerment of Cooperatives and Micro, Small and Medium Enterprises. The change in the status of a legal entity must be carried out by means of a notary deed and subject to the legal provisions concerning the company (Article 9 paragraph (3) PP Company)

\section{The form of legal liability for private companies (MSMEs)}

Even though it is established by only 1 (one) person, the legal liability for an individual company follows that of a company in general. Limited liability is adopted in individual companies, meaning that the shareholders (founders) are only responsible for the amount of shares they own. This is stated in Article 153J paragraph (1) of the Job Creation Law, namely "The shareholders of the Company for Micro and Small Enterprises are not personally responsible for the engagement made on behalf of the Company and are not responsible for the Company's losses exceeding the shares owned." However, the shareholder (founder) becomes responsible up to his personal assets, if (Article 153J paragraph (2) of the Job Creation Law): the requirements of the Company as a legal entity have not been or are not fulfilled; shareholders in bad faith use the Company for personal gain; shareholders are involved in illegal acts committed by the Company; or shareholders unlawfully use the Company's assets, which results in the Company's assets being insufficient to pay off the Company's debts.

\section{Dissolution of Pt.Perseorangan (MSMEs)}

Dissolution of an Individual Company must be carried out through a Decree of the Shareholders of an Individual Company. This decision has legal force like the General Meeting of Shareholders (GMS). The decree is set forth in the Declaration of Disbandment and notified electronically to the Minister (Article 13 paragraph (1) PP Company). The reasons for the dissolution are as follows: Based on the shareholder's decision; The standing period has ended; 
This work is licensed under a Creative Commons Attribution-ShareAlike 4.0 International License

Based on court order; with the revocation of bankruptcy based on the decision of the commercial court which has permanent legal force, the bankruptcy assets of an individual Company are not sufficient to pay bankruptcy costs; Bankrupt assets of an individual company that has been declared bankrupt are in a state of insolvency as regulated in the bankruptcy law and postponement of debt payment obligations; or The revocation of the business license of an individual Company so that it requires an individual Company to carry out liquidation by filling out a Statement of dissolution. In order to attract MSMEs players, this Individual Company receives a fee waiver for its establishment. Its establishment does not require a notary deed. In addition, the founders of the company act directly as directors. Finally, a Company Founder can only establish 1 (one) Individual Company in a year.

\section{Concept of Bankruptcy in Companies}

In Indonesia, formally, bankruptcy law has existed and there has even been a special law since 1905 with the enactment of Staatsblad 1905-217 juncto Staatsblad 1906-348. In fact, in everyday life people are familiar with the words bankrupt. The Staatsblad 1905- 127 and Staatsblad 1906-348 were later amended by Legislation No. 1 of 1998, which was later accepted by the House of Representatives (DPR) so that it became Law No. 4 of 1998. Law No. 1 of 1998 is on Amendments to the Bankruptcy Act, which was then revised by Act No. 37 of 2004 on Bankruptcy and Suspension of Payment (Munir Fuady,:2014) Bankruptcy is a situation in which the debtor is unable to make the payments to debts from its creditors. The condition of being unable to pay is usually due to financial distress from the debtor's business which has experienced a setback. ( M. Hadi Shubhan: 2009) Meanwhile, bankruptcy is a decision issued by the Court which results in general confiscation of all assets owned and assets. which will be owned by the debtor at a later date. The management and settlement of bankruptcy are carried out by the curator under the supervision of the supervisory judge, the two officials who are directly appointed at the time the bankruptcy decision is read. According to Article 2 paragraph (1) of Law Number 37 Year 2004 (UUKPKPU) which defines bankruptcy as follows: "A debtor who has two or more creditors and does not pay in full at least one debt that has matured and can be collected, is declared bankrupt with a verdict. the court either at its own request or at the request of one or more creditors. Requirements to be declared bankrupt:

a. There is a state of stopping paying, that is, when a debtor is unable or unwilling to pay his debts.

b. There must be more than one creditor, and one of them, the debt is already collectible. In general, for a statement of bankruptcy it does not need to show that the debtor is unable to 
pay his debt, and does not care, whether to stop paying it as a result of not being able to or dont want to pay.

According to Article 2 of Law Number 37 Year 2004 concerning bankruptcy, the applicant in a bankruptcy case is one of the following parties:

1. The debtor itself.

2. One or more creditors.

3. The prosecutor's office when it comes to public interest.

4. Bank Indonesia if the debtor is a bank.

5. The Capital Market Supervisory Agency if the debtor is a securities company, stock exchange, clearing and guarantee institutions, as well as a depository and settlement agency.

6. The minister of finance if the debtor is an insurance, reinsurance, pension fund, or BUMN company engaged in the public interest.

Due to the absence of the involvement of the Notary as in the Capital Alliance Limited Liability Company in general. The process of establishing and ratifying an individual PT legal entity is considered to be simpler than that of an ordinary PT. Because it is intended specifically for MSEs so that MSMEs can obtain legal entity status by simply registering and showing proof of registration of PT.Perseoranagan in the AHU system electronically. PT. Individuals who have become legal entities will be able to easily apply for capital loans from third parties / banks to advance their business. The establishment of this PT can be done by making a statement of establishment and filling out forms directly online via a web platform or mobile phone application. In fact, third party assistance is also opened to accommodate MSMEs. The legal entity ratification process is fast due to electronic registration. After all required forms and documents are complete and have paid the establishment fee. MSE players are fully responsible for the accuracy of the information conveyed in the filling in the form they submit.

In Law Number 11 of 2020 concerning Job Creation, there are new things, namely Micro and Small Companies which are regulated in Article 153 which is divided into 10 Articles (153A, 153B, 153C, 153D, 153E, 153F, 153G, 153H, 153I, 153J ), among these Articles relating to the establishment of a company are as follows:

Article 153A

1) Companies that meet the criteria for Micro and Small Enterprises can be established by 1 (one) person.

2) The establishment of a Company for Micro and Small Businesses as referred to in paragraph shall be based on a statement of establishment made in Indonesian. 
This work is licensed under a Creative Commons Attribution-ShareAlike 4.0 International License

3) Further provisions regarding the establishment of a Company for Micro and Small Enterprises are regulated in a Government Regulation.

Regarding the form of the company owned by a person previously existed in Countries that embrace lawsystem thecommon such as America, Britain, and Malaysia are Company yangdimiliki by one person and has limited liability. However, the legislation of that State governing the enterprise(company)have restrictions are very strict. (NindyoPramono, 2011). In addition, shareholders in micro and small companies also have a limited responsibility like a non-microsmall company, this is confirmed in Article $153 \mathrm{~J}$ paragraph (1), which reads: "Company shareholders for Micro and Small Enterprises are not personally responsible. for an engagement made on behalf of the company and not responsible for the company's losses in excess of the shares it owns". We know that this PT Perorangan is a sole proprietorship, so that the form of responsibility is only up to the paid-up capital. The dissolution process is also considered very simple and carried out electronically, however, the company liquidation and settlement process does not follow what is stated in the applicable Company Law, where at PT Persekutuan Modal (PT Ordinary) which is dissolved, namely a GMS with a Notarial deed, then by appointing a Liquidator / Board of Directors or other party, but different from PT Perorangan related to the dissolution, namely by only making a Share Decision Statement, then this Sole shareholder appoints a Liquidator, which can be the Owner or the Board of Directors, for the Owner and the Board of Directors are single or the same person.

PT Perorangan does not mention the existence of a Commissioner, where the Commissioner is in charge of supervising the related Directors. So that it seems that there is a high probability that the Directors of PT Perorangan will make mistakes or negligence, one of which causes PT. The individual is declared bankrupt and experiences insolvency. If PT. The individual has been declared bankrupt by the court so it is clear that there will be dissolution. In PP No. 8 of 2021 concerning the Authorized Capital of the Company and the Registration of Establishment, Amendment and Disbursement of Companies that Meet the Criteria for Micro and Small Businesses, it is not regulated and explained in detail regarding the dissolution of PT due to bankruptcy, will automatically open the opportunity to dispute with third parties.

It is recommended that PT. Individuals still have the same organ structure as a Limited Liability Company (Ordinary PT), namely the existence of the GMS, the Board of Directors and the Board of Commissioners, even though the three organs are held by the same person. This needs to be clearly stated in the statement of the establishment of an individual PT as well as changes in its composition if any. In line with the number of shareholders who are one person, the minimum number of directors and commissioners is 1 (one) person each. The responsibilities of the board of directors (fiduciary duty) and the board of commissioners are the same as those of an ordinary PT. 
This work is licensed under a Creative Commons Attribution-ShareAlike 4.0 International License

So that in making the Statement of Establishment of PT Perorangan, a clause on the mechanism of accountability for third parties is made clearly and in detail if the PT is experiencing bankruptcy, this will make both parties, both the debtor (PT. Perorangan) and the creditor (BANK) no one is harmed.

\section{Forms of Legal Protection Against Third Parties (BANK) When PT. Individuals (MSMEs) are declared bankrupt.}

\section{Forms of legal protection for third parties (BANK)}

The existence of arequirement concursus creditorium is a consequence of the enactment of the provisions of Article 1131 Burgerlijk Wetboek where the bankruptcy ratio is the fall in general confiscation of all debtor's assets, then after a debt-receivable verification meeting does not reach peace or accoord, a liquidation process is carried out for all debtor's assets to then distribute the proceeds to all creditors according to the order of creditors' level as regulated by Article 1132. The Civil Code states that all debtor's assets become joint guarantees for his creditors, and if the bankrupt debtor who is used as collateral in the settlement of his debts is transferred or sold to a third party, then the assets can be returned to their original state withdemands Actio Pauliana's accepted by h court. Actio Pauliana can be interpreted as a creditor's or curator's right to demand the cancellation of a debtor's legal action which harms his creditors, this authority is generally regulated in Article 1341 of the Civil Code. Indonesia as a state based on law is stated in Article 1 paragraph (3) of the 1945 Constitution of the Republic of Indonesia. It is the state's obligation to guarantee the rights of every citizen by providing these rights in the form of legal protection. Legal protection is the right of every citizen and should be implemented as best as possible. Likewise, legal protection must be given to a third party to claim their right to cancellation with the debtor due to the existence of Actio Pauliana. Creditors through actio pauliana are given an effort to prosecute the rights of the debtor (Ida ayu Kade Winda Swari: 2014) Which can be said to be actio pauliana, namely;

1. A right or legal protection that is owned by a creditor at any time if he feels aggrieved.

2. An action taken by a debtor to transfer his / her rights to property that is detrimental to his creditor if he feels that he is threatened to be declared bankrupt in bad faith.

3. One thing that must be proven with whom the debtor has taken legal action as mentioned above is that the "debtor" knows that the act committed can harm the creditor (Adrian Sutedi; 2009).

With the existence of a bankruptcy statement addressed to the debtor, the debtor for the sake of the law since the day declared bankruptcy loses the right to control his assets, and who subsequently takes care of the activities and settlement of the debtor's bankruptcy is taken over by the curator, this is the duty and authority of the curator (Kadek Indra Dewantara: 2019) states that 
This work is licensed under a Creative Commons Attribution-ShareAlike 4.0 International License

rights owned by third parties must be protected against objects obtained in good faith. Likewise, the Civil Code states in Article 1341 that the rights obtained by third parties in good faith over the objects that become objects must be protected. As for the explanation regarding Article 49 paragraph (3), namely "the rights of third parties over objects as referred to in paragraph (1) which are obtained in good faith and not for free, must be protected." In connection with the article above, Article 49 paragraph (4) states that "objects received by the debtor or its replacement value must be returned by the curator as long as the bankruptcy property benefits, while for the shortcomings, the person against whom the cancellation can appear as a concurrent creditor." Observing the article above, it can be understood that the third party will receive a replacement value if the bankruptcy assets are sufficient to settle the bankruptcy or in other words there is time to replace it. If the bankruptcy assets are not sufficient in resolving the bankruptcy, compensation for losses suffered by third parties can be prosecuted by appearing only as a concurrent creditor.

The position of the third party as a concurrent creditor does not guarantee that he will receive compensation with the same value as issued, the problem is that the debtor's bankruptcy assets that have been auctioned are in the hands of a third party after the assets have been shared with the preferred creditor, so that legal protection for the party The third form of legal protection is that the third party can appear as a concurrent creditor whose debt repayment is sufficient from the sale and auction of the debtor's bankruptcy assets whose first part has been divided by separatist or preferred groups, and the second form of third party legal protection, namely by a means of legal protection (coercion) repressive where protection is given to legal subjects in terms of dispute resolution that enter the realm of the court.

\section{CONCLUSION}

The legal consequences for a third party (BANK) if a PT. Individual is declared bankrupt will affect the position of the third party (BANK) as a Financing Institution where the government should formulate regulations on MSMEs that clearly state the responsibility mechanism of PT. to a third party if the PT is experiencing bankruptcy, in which the role of the third party (BANK) is to assist PT. Individuals to develop the MSMEs business. It is recommended that PT. Individuals still have the same organ structure as a Limited Liability Company (Ordinary PT), namely the existence of the GMS, the Board of Directors and the Board of Commissioners, even though the three organs are held by the same person. This needs to be clearly stated in the statement of the establishment of an individual PT as well as changes in its composition if any. In line with the number of shareholders who are one person, the minimum number of directors and commissioners is 1 (one) person each. The responsibilities of the board of directors (fiduciary duty) and the board of commissioners are the same as those of an ordinary PT. So that in making the Statement of 
This work is licensed under a Creative Commons Attribution-ShareAlike 4.0 International License

Establishment of PT Perorangan, a clause on the mechanism of accountability for third parties is made clearly and in detail if the PT is experiencing bankruptcy, this will make both parties, both the debtor (PT. Perorangan) and the creditor (BANK) no one is harmed.

The Government does not state clearly and in detail in the formulation of UUCK and in Government Regulation Number 8 of 2021 concerning Third Party (BANK) protection if PT. Individuals go bankrupt, but the Government has prepared weapons of war for PT. Individuals (MSMEs) if any other parties are suing, the Government has prepared full legal assistance for the PT. the individual and also the role of the Notary was not involved at all. It would be nice for the Government when formulating the rules on UUCK, especially regarding MSMEs, it must be clearer and more detailed so that when the regulation has been formalized, the public and especially financial institutions can be protected by the interests of the parties concerned. The government should be able to minimize the risk of a lawsuit against the private PT (MSMEs), namely by providing clear and detailed rules in these rules. Then the role of a notary should be involved to guarantee the legal certainty of the parties concerned because of the notary's impartial nature, and the notary can also transcribe the agreement in the form of an authentic deed so that the interests of the parties can be protected if one of the parties fails to fulfill his / her achievement (default), or maybe the debtor is in a difficult / difficult situation, or he is also in bankruptcy. So that in PP Number 7 of 2021 not only PT. Individuals (MSMEs) can get legal protection, but financing institutions or third parties (BANK) can also protect their interests.

\section{REFERENCES}

Adrian Sutedi (2009), Bankruptcy Law, Bogor: Ghalia Indonesia.

Dijan Widijowati, (2012). Commercial Law, Yogyakarta: Andi Offset.

Herlin Budiono (2017), Basic Technique of Making Notary Deeds, Bandung: PT. Cotra Aditya Bakti.

Ida ayu Kade Winda Swari (2014), Legal Protection of Creditors' Interests Due to Actio Pauliana in Bankruptcy Law", Kertha Semaya.

Kadek Indra Dewantara (2019) Authority of Curators in Managing and Controlling Bankrupt Debtor's Assets ”, Kertha Semaya, Vol. 7, No. 9.

M. Yahya Harahap, (2019). Limited Liability Company Law, Jakarta: Sinar Grafika.

Munir Fuady, Bankruptcy Law in Theory and Practice (2014) Bandung: PT. Citra Aditya Bakti.

M. Hadi Shubhan (2009), Bankruptcy Law: Principles, Norms and Practices in Justice, Jakarta: Kencana. 
ManSastrawidjaya (2006), Bankruptcy Law and Postponement of Debt Payment Obligations, Bandung: Alumni.

Peter Mahmud Marzuki, (2011). Legal Research, Jakarta: Kencana Prenada Media Group.

Rusliati, E. (2020). An Innovation for the Resilience and Development of MSMEs in Majalengka Regency, Indonesia. 6th International Conference on Social and Political Sciences (ICOSAPS 2020), 632-643.

Yustianti, S., \& Roesli, M. (2018). Bank Indonesia Policy in the National Banking Crisis Resolution. YURISDIKSI: Jurnal Wacana Hukum Dan Sains, 11(1), 77-90.

Zainal Asikin \& Wira Pria Suhartana, (2016). Introduction Company Law, First Edition, Jakarta: Prenada Media Group. 